\title{
EKSPERIMENTASI STRATEGI PEMBELAJARAN THE POWER OF TWO PADA MATERI KULIAH MENULIS PANTUN DITINJAU DARI HASIL BELAJAR MAHASISWA PENDIDIKAN BAHASA DAN SASTRA INDONESIA FKIP UMSU
}

\author{
Mutia Febriyana, M.Pd. ${ }^{1}$, Winarti, M.Pd. ${ }^{2}$ \\ Universitas Muhammadiyah Sumatera Utara, Indonesia
}

Penelitian ini bertujuan untuk mengetahui, (1) Apakah strategi pembelajaran the power of two dapat memberikan hasil belajar yang lebih baik pada materi kuliah menulis pantun, (2) Apakah strategi pembelajaran konvensional dapat memberikan hasil belajar yang lebih baik pada materi kuliah menulis pantun, (3) Manakah diantara strategi pembelajaran the power of two dan konvensional yang lebih baik ditinjau dari hasil belajar mahasiswa pada materi menulis pantun. Penelitian ini menggunakan metode eksperimen. Populasi penelitian ini adalah seluruh Mahasiswa Semester VI Program Studi Pendidikan Bahasa dan Sastra Indonesia FKIP UMSU. Sampeldalampenelitianiniadalah mahasiswa semester VI kelas BpagisebagaikelaseksperimendankelasB soresebagai kelas kontrol.Instrumen yang digunakan untuk mengumpulkan data dalam penelitian ini adalah tes esai. Hasil analisis menunjukkan bahwa rata-rata hasil belajar siswa yang menggunakan strategi pembelajaran konvensional dalam menulis pantun lebih rendah dari pada rata-rata hasil belajar siswa yang menggunakan strategi pembelajaran the power of two dalam menulis pantun yakni 91,15. Simpulan penelitian ini adalah hasil belajar mahasiswa menggunakan strategi the power of two lebih baik dibandingkan dengan menggnakan strategi pembelajaran konvensional.

Kata Kunci: The Power of Two, Hasil Belajar Menulis Pantun

\section{PENDAHULUAN}

\section{Latar Belakang Masalah}

Kesulitan menulis masih menjadi dilema bagi mahasis wa yakni mampu menulis dengan baik dan benar, terutama menulis pantun sebagai salah satu karya sastra. Menulis bagi mahasiswa tidak semudah yang dibayangkan. Oleh karena itu, perlu adanya penyegaran dengan cara yang dapat membuat mahasiswa aktif, kreatif, inovatif, efektif, dan merasa senang mengikuti aktivitas pembelajaran menulis. Jika hal tersebut dapat dilakukan oleh Dosen, maka proses belajar mahasiswa akan lebih bermakna dan mencapai tujuan (hasil belajar) yang diharapkan. Mahasiswa semester VI Program Studi Pendidikan Bahasa dan Sastra Indonesia FKIP UMSU yang peneliti temui dikelasnya masing- masing, peneliti menemukan bahwa mahasiswa kurang merespon terhadap kemampuan menulis. Mereka beranggapan bahwa menulis merupakan keterampilan yang sukar dimiliki. Berbagai tulisan yang pernah diamati, sedikit sekali dari mereka yang kreatif menulis. Hal ini dapat dilihat dari hasil tulisan yang sudah mereka publikasikan diberbagai tempat, masih minim dari segi kuantitas dan kualitas. Selain itu, keterbatasan kemampuan mahasiswa dalam menguasai keterampilan menulis dapat dipengaruhi oleh beberapa factor yakni pembelajaran menulis di kelas yang belum maksimal, kemampuan dosen dalam mendukung kemampuan menulis 
mahasiswa, kurangnya kesadaran mahasiswa tentang manfaat dan pentingnya menulis, minimnya minat dan partisipasi mahasiswa dalam pembelajaran menulis.

Menulis puisi lama merupakan salah satu kegiatan dari sastra. Fauzi (2014: 3) menyatakan bahwa,"Salah satu kebudayaan Indonesia yang banyak terlupakan orang adalah pantun karena sebagian orang hanya mengingat satu atau dua pantun yang sering terdengar saja, padahal pantun Indonesia sangat beragam, baik itu dari jenisnya maupun bentuk dan isinya”. Pantun dapat digunakan oleh masyarakat untuk berkenalan, menyampaikan nasehat, bercanda, dan berkomunikasi satu sama lain dengan bahasa lebih singkat tanpa kalimat terlalu panjang. Bahkan di Universitas Muhammadiyah Sumatera Utara (UMSU) sendiri, pihak Rektorat dan Fakultas telah beberapa tahun ini mengembalikan pantun pada tempatnya yang agung, sehingga jika ada tamu yang datang baik dari dalam maupun dari luar negeri pihak rektorat dan fakultas selalu menyambut tamu dengan pantun. Jikapun acara yang dibuat adalah acara lokal, UMSU tetap mulai membudidayakan tradisi berpantun. Sayangnya, mahasiswa sendiri masih menganggap bahwa pantun adalah budaya langka yang hanya orang-orang tua saja yang bias menulisnya atau hanya para pengajar sastra saja yang mampu menuliskannya, padahal siapa saja bisa menulis pantun. Peneliti menemukan permasalahan ini ketika mahasiswa memperoleh materi kuliah tentang puisi lama yang salah satu pembagian pada puisi lama itu yaitu pantun. Mahasiswa membutuhkan waktu lama untuk menuliskan pantun. Pada kondisi lain, Mahasiswa salah teknik dalam membuat pantun (antara sampiran dan isi terbalik) serta melanggar persyaratan pantun lainnya yang berupa rima dan jumlah suku kata dalam tiap larik. Kemampuan mahasiswa juga masih belum menunjukkan hasil belajar baik disebabkan oleh suasana pembelajaran menulis pantun cenderung membosankan sehingga berdampak pada hasil belajar mahasiswa dalam menulis salah satu karya sastra ini rendah.

Berdasarkan uraian diatas, peneliti tertarik untuk mengadakan penelitian dengan judul "Eksperimentasi Strategi Pembelajaran The Power of Two pada Materi Kuliah Menulis Pantun ditinjau dari Hasil Belajar Mahasiswa Pendidikan Bahasa dan Sastra Indonesia FKIP UMSU”.

\section{KAJIAN PUSTAKA}

\section{Strategi Pembelajaran The Power of Two}

Strategi pembelajaran the power of two termasuk bagian dari active learning yang merupakan salah satu cara terbaik untuk meningkatkan belajar lebih aktif dengan pemberian tugas belajar yang dilakukan dalam kelompok kecil mahasiswa. Dukungan sesama mahasiswa dan keragaman pendapat,pengetahuan, serta keterampilan mereka akan membantu menjadikan belajar sebagai bagian berharga di kelas.

Hamruni (2013: 160) mengatakan bahwa strategi pembelajaran the power of two bertujuan untuk menunjukkan bahwa belajar secara berpasangan akan lebih baik hasilnya dibanding belajar secara sendiri-sendiri. Kemudian menurut Zaini (2008: 52), "Aktivitas 
pembelajaran ini digunakan untuk mendorong pembelajaran kooperatif dan memperkuat arti penting serta manfaat sinergi dua orang. Strategi ini mempunyai prinsip bahwa berpikir berdua jauh lebih baik daripada berpikir sendiri."

Dari pendapat di atas dapat disimpulkan bahwa strategi pembelajaran the power of two adalah strategi yang digunakan untuk meningkatkan pembelajaran kolaboratif (bersama), menumbuhkan kerjasama secara maksimal,dan memperkuat arti penting manfaat sinergi dua orang (dua kepala lebih baik daripada satu), dalam pembelajaran ini mahasiswa akan berkolaborasi dengan temannya (dua orang) untuk memperkuat pemahaman individu masingmasing.

\section{Langkah-langkah Penerapan Strategi Pembelajaran The Power of Two}

Adapun langkah-langkah yang ditempuh dalam menerapkan strategi pembelajaran the power of two sebagai berikut:

1. Dosen menerapkan tindakan yang mengacu pada skenario pembelajaran.

2. Mahasiswa menyimak penjelasan singkat dosen terkait materi yang akan didiskusikan yakni menulis pantun. Dosen telah menyampaikan tindakan yang akan diuji cobakan pada pertemuan minggu sebelumnya agar kegiatan belajar mengajar tidak terganggu.

3. Dosen menugaskan siswa untuk duduk berpasang-pasangan.

4. Dosen meminta mahasiswa untuk menulis pantun secara berpasang-pasangan dengan tema jenis pantun yang disesuaikan.

5. Dosen memberikan kesempatan kepada penulis pantun yang berpasangan tersebut untuk maju ke depan kelas untuk membacakan hasil pantunnya.

6. Dosen meminta mahasiswa memberi tanggapan terhadap hasil pantun pasangan kelompok.

7. Dosen mengajak mahasiswa membuat rangkuman yang mengacu pada kompetensi yang ingin dicapai dan hasil menulis pantun dikumpulkan kepada dosen.

\section{METODE PENELITIAN}

Penelitian ini menggunakan metode eksperimen. Populasi penelitian ini adalah seluruh Mahasiswa Semester VI Program Studi Pendidikan Bahasa dan Sastra Indonesia FKIP UMSU. Sampel dalam penelitian ini adalah mahasiswa semester VI kelas B Pagi sebagai kelas eksperimen dan kelas B Sore sebagai kelas kontrol. Instrumen yang digunakan untuk mengumpulkan data dalam penelitian ini adalah tes esai. Objek dalam penelitian ini adalah Eksperimentasi Strategi Pembelajaran The Power of Two pada Materi Kuliah Menulis Pantun ditinjau dari Hasil Belajar Mahasiswa Pendidikan Bahasa dan Sastra Indonesia FKIP UMSU. Desain penelitian yang digunakan adalah posttes-only control design. Lokasi penelitian dilakukan di Ruang Kuliah Fakultas Keguruan dan Ilmu Pendidikan Universitas Muhammadiyah 
Sumatera Utara Jalan Mukhtar Basri Nomor 3 Medan. Waktu penelitian dilakukan pada Tahun Akademik 2017-2018.

\section{HASIL PENELITIAN DAN PEMBAHASAN}

\section{Hasil Penelitian}

Setelah dilakukan penelitian tentang Eksperimentasi Strategi Pembelajaran The Power of Two pada Materi Kuliah Menulis Pantun ditinjau dari Hasil Belajar Mahasiswa Pendidikan Bahasa dan Sastra Indonesia FKIP UMSU maka diperoleh hasil berikut:

1. Deskripsi skor kemampuan menulis pantun dengan menggunakan strategi pembelajaran The Power of Two

Langkah awal yang dilakukan oleh peneliti yakni mencari skor mentah tiap-tiap mahasiswa yang diberi perlakuan strategi pembelajaran the power of two. Skor tertinggi mahasiswa yang diajar dengan strategi pembelajaran the power of two adalah 15 dan yang paling rendah adalah 10. Diketahui bahwa nilai rata-rata hasil belajar menulis pantun adalah 91,15. Hal ini berarti kemampuan menulis pantun diajar menggunakan strategi pembelajaran the power of two berada pada tingkat baik. Oleh karena itu, The Power of Two merupakan salah satu jenis strategi belajar mengajar yang sesuai untuk materi kuliah menulis pantun (Gulo, 2008).

2. Deskripsi skor kemampuan menulis pantun dengan menggunakan strategi pembelajaran Konvensional

Peneliti melakukan pencarian skor mentah tiap-tiap mahasiswa yang diberi perlakuan strategi pembelajaran konvensional. Skor tertinggi mahasiswa yang diajar dengan strategi pembelajaran the power of two adalah 12 dan yang paling rendah adalah 5. Diketahui bahwa nilai rata-rata hasil belajar menulis pantun adalah 56,97. Hal ini berarti kemampuan menulis pantun diajar menggunakan strategi pembelajaran konvensional berada pada tingkat rendah.

\section{Pembahasan Penelitian}

Berdasarkan hasil analisis nilai tes menulis pantun pada mahasiswa/i semester VI Pendidikan Bahasa dan Sastra Indonesia FKIP UMSU yang telah dibagi menjadi dua kelas yakni kelas eksperimen dan kelas kontrol menunjukkan bahwa kedua kelas tersebut adalah homogen. Hal tersebut menyatakan bahwa data memiliki distribusi normal dan memiliki varian yang tidak berbeda secara signifikan. Kondisi awal menunjukkan bahwa mahasiswa masih dalam kondisi yang sama sebelum diberi perlakuan. Kelompok kelas eksperimen yang diberi perlakuan dengan menggunakan strategi pembelajaran the power of two dan kelompok kelas kontrol yang diberi perlakuan metode pembelajaran konvensional yang biasa dosen lakukan dalam kegiatan pembelajaran. Setelah diberi perlakuan pada kelompok kelas eksperimen dan kelompok kelas kontrol dilakukan tes kemampuan menulis pantun. Pembelajaran dengan strategi pembelajaran the power of two yang telah dilakukan dapat 
memberikan motivasi mahasiswa dalam menulis pantun sehingga mahasiswa mampu membangun ide dan gagasan kreatif serta terampil menulis pantun.

Kelompok kelas kontrol menggunakan metode pembelajaran konvensional dalam kegiatan pembelajaran. Penggunaan metode pembelajaran konvensional menyebabkan peran dosen lebih aktif daripada mahasiswa dikarenakan dosen cenderung lebih banyak menyampaikan materi sehingga mahasiswa menjadikan dosen sebagai pusat informasi dalam pembelajaran. Keaktifan mahasiswa dalam proses belajar menjadi tidak efektif karena metode pembelajaran ini hanya berpusat pada dosen. Dosen menjelaskan materi, mempersiapkan dan mengelola bahan ajar kemudian menyampaikan informasi terkait bahan ajar kepada mahasiswa. Hasil penelitian menunjukkan bahwa kemampuan menulis pantun pada kelas ekperimen lebih baik dibandingkan mahasiswa kelas kontrol. Perbedaan hasil tes kemampuan menulis pantun tersebut dikarenakan kelompok kelas eksperimen diberikan perlakuan melalui strategi pembelajaran the power of two yakni berpasang-pasangan saling membangun ide dan gagasan untuk menemukan solusi terhadap kendala menulis pantun.

Berdasarkan hasil penelitian yang dilakukan dapat diambil simpulan bahwa hasil belajar mahasiswa menggunakan strategi the power of two lebih baik dibandingkan dengan menggnakan strategi pembelajaran konvensional. Hal ini terlihat dari nilai rata-rata kemampuan menulis pantun mahasiswa pada kelas eksperimen dengan menggunakan strategi pembelajaran the power of two adalah 91.15. Sementara itu, nilai rata-rata kemampuan mahasiswa menulis pantun pada kelas kontrol dengan menggunakan metode pembelajaran konvensional adalah 56.97. Dengan kata lain, nilai rata-rata yang diperoleh pada kelas eksperimen jika dibandingkan dengan kelas kontrol yaitu (91.15>56.97 ). Dengan kata lain, penggunaan strategi pembelajaran the power of two memiliki dampak positif yang nyata dan lebih baik terhadap kemampuan menulis pantun mahasiswa semester VI Pendidikan Bahasa dan Sastra Indonesia FKIP UMSU.

\section{PENUTUP}

Penggunaan strategi pembelajaran the power of two dapat mempengaruhi kemampuan mahasiswa dalam menulis pantun. Hal ini ditandai dengan nilai rata-rata yang lebih tinggi pada kelas eksperimen, sehingga dapat disimpulkan bahwa penggunaan strategi pembelajaran the power of two memiliki pengaruh yang nyata dan lebih baik terhadap kemampuan menulis pantun. Berdasarkan penelitian yang dilakukan, strategi pembelajaran the power of two dapat direkomendasikan dalam proses belajar mengajar di universitas-universitas khususnya pada program studi pendidikan bahasa dan sastra Indonesia pada pembahasan tentang pantun.Pemberian tugas cara menulis pantun dengan menggunakan strategi pembelajaran the power of two dapat menjadi tambahan model pembelajaran bagi dosen untuk meningkatkan hasil belajar dan motivasi mahasiswa dalam belajar bahasa dan sastra. 


\section{DAFTAR PUSTAKA}

Arikunto, Suharsami. 2013. Prosedur Penelitian Suatu Pendekatan Praktik. Jakarta: Rineka Cipta.

Depdiknas.2007.KamusBesarBahasaIndonesia.Jakarta:Gramedia

Depdiknas.2012.KamusBesarBahasaIndonesia.Jakarta:Gramedia.

Fauzi,M.Miftah.2014.Kamus Lengkap Pantun Indonesia. Jakarta: Publishing Langit.

Gie,The Liang. 2002. Terampil Mengarang. Yogyakarta: Andi.

Hamruni, S. 2013. Metode Pembelajaran Berbasis Masalah. Yogyakarta : Kanisius.

Kosasih, E. 2008. Apresiasi Sastra Indonesia. Jakarta: Nobel.

Poerwadarminta.2005. Bahasa Indonesia untuk Karang-mengarang.Yogyakarta: U.P.

Ruseffendi. 2005. Dasar-dasar Penelitian Pendidikan \& Bidang Non-Eksata. Lainnya. Bandung: Tarsito.

Sugiyono. 2010. Metode Penelitian Pendidikan Pendekatan Kuantitatif, Kualitatif, dan $R \& D$. Bandung: Alfabeta.

Tarigan,Hendri Guntur.1985. Menulis sebagai Suatu Keterampilan Berbahasa. Bandung: Angkasa.

Umry,Shafwan Hadidan Winarti.2011. Sastra Mandiri: Telaah Puisi. Medan: Format Publishing.

Zaini, Hisyam.2008. Srategi Pembelajaran Aktif. Yogyakarta: Insan Mandiri. 